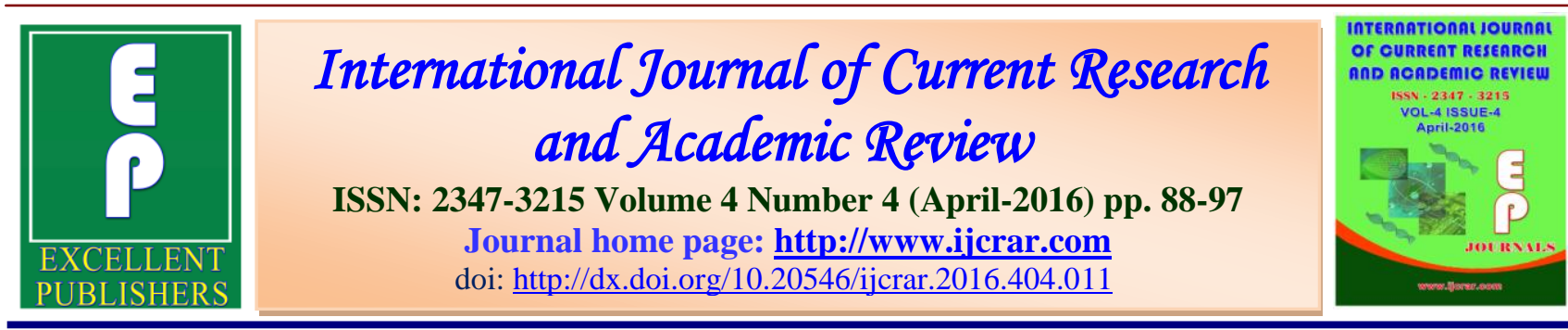

\title{
Isolation of L-asparaginase Producing Actinomycetes from Marine Sediments
}

\section{P. Dhevagi ${ }^{1}$ * and E. Poorani ${ }^{2}$}

${ }^{1}$ Department of Environmental Sciences, Tamil Nadu Agricultural University, Coimbatore - 641 003, Tamil Nadu, India

${ }^{2}$ Department of Biotechnology, Government College of Technology, Coimbatore - 641 003,

Tamil Nadu, India

*Corresponding author

\begin{tabular}{l|l} 
KEYWORDS & A B S T R A C T
\end{tabular}

L-asparaginase,

Actinomycetes,

Marine

Environmental factors in the marine environment forces the marine organisms to be the source of useful bioactive compounds. Among the marine organisms, Actinomycetes gained importance as they play a vital role in the

Sediments,

Ammonium production novel metabolites. To explore the potential of marine Actinomycetes the present study was carried out. Eight isolates with different Sulphate. growth pattern was isolated from marine sediments of Thiruvallum, Kerala using starch casein agar medium. Large size, white colored colonies with fibre like growth surrounding the colonies were observed in starch casein agar media. All the isolates were subjected to rapid plate assay technique for screening L asparaginase activity. Starch casein agar supplemented with $0.015 \%$ phenol red was highly suitable for assessing asparaginase activity. Only three isolates showed significant activities and KTI7 showed highest zone of clearance. The crude enzyme obtained from the promising isolate KTI7 was purified by salting out with ammonium sulphate followed by sephadex gel filtration.

\section{Introduction}

Marine environment is providing a habitat for microbes with unique properties since they have to adapt to extreme environmental conditions like high and low temperature, acid and alkyl conditions, high pressure, limited nutrients etc. (Baharum, 2010). These distinctive properties attracted many researchers to explore the marine depth. due to the fact that they are adapted to a marine habitat. Marine Actinomycetes provide a good source of new secondary metabolites because they have a different biochemistry from the terrestrial due to the fact that they are adapted to a marine habitat. They produce extracellular enzymes which are alkalophilic or acidophilic in nature and contains high proportion of acidic or basic amino acids, hence shows good stability 
especially during the synthesis of compounds of medicinal importance (Lee et al., 1989; Adams et al., 1995).

L-Asparaginase is produced by marine microorganism and it has received much attention because of its antitumour activity in guinea pig serum (Broome, 1971). Selvakumar et al. 1977 observed that the marine sediments harbour potential Lasparaginase enzyme producers. Savitri and Azmi, 2003 found that like bacteria, actinomycetes are also good source of Lasparaginase and was proved to be promising for the treatment of acute lymphocytic leukaemia. Sabu, (2003) reported that L-asparaginase could be effectively used for the treatment of lymphoblastic leukemia and tumour cells. Dhevagi and Poorani, 2006 isolated the tumour inhibiting L-asparaginase from marine actinomycetes and found that the enzyme synthesis was more in starch casein broth. Now a days more than a dozen marine alkaloids are involved in different phases of clinical trials for the treatment of human tumours (Newman and Hill, 2006). Sindhwd and Desai, 2015 reported that the glutaminase activity was found to be 3.5 times lower than the asparaginase activity.

Although various organisms have the potential for L-asparaginase production (Kotzia and Labrou, 2007; Alapati and Muvva, 2012; Prakasham et al., 2010; Thenmozhi et al., 2011 and Natra et al., 2011), their therapeutic use were limited due to immunological responses (Ramya et al., 2012). L-asparaginase catalyses the hydrolysis of asparagine into aspartic acid and ammonia. It exploits the dependency of leukemia cells which depends on exogenous source of L-asparaginase since these cells are not capable of synthesing asparagines. L-asparaginase deplete the asparagine supply to Leukemia cells which leads to death of the cells.

Marine actinomycetes are expected to have halophilic enzymes with unique structures. Although some work has been done on marine actinomycetes not much work has been done with marine sediment microflora of south coastal areas of India, which is a unique habitat and hence there is a potential for new species with novel therapeutic activity. In order to explore the marine Actinomycetes with therapeutic properties, the present study was planned.

\section{Materials and Methods}

\section{Isolation of Actinomycetes from Marine Sediments}

Marine sediments were collected from brackish water sediments at Thiruvallam, Kerala. All the samples were collected by inserting a polyvinyl corer (10 cm dia.) into the sediments and care was taken while selecting the locations that it had as widely varying characteristics as possible. The sediment samples were analyzed as per the standard procedures (APHA, 1989 and Cappuccino and Sherman, 2002).

Pretreatment of sediment was done to improve the population of Actinomycetes (Ellaiah and Reddy, 1987). Several different combinations of media have been suggested for the isolation of actinomycetes from soil (Waksman, 1961). Out of 21 recommended media, starch casein agar medium (Shirling and Gottlieb, 1966) was used for the enumeration. Loopful of inocula from the pre-enriched broth of starch casein was streaked and the plates were incubated at $37^{\circ} \mathrm{C}$ for 7 days. After incubation, a total of eight isolates were obtained which were further screened for L-asparaginase 
production and the single colonies were subcultured for further identification.

\section{Characterization of the Isolates}

Pure cultured colonies were subjected to morphological, cultural and biochemical characterization to identify the organisms, using standard procedures. The cultural characteristics were studied in accordance with the guidelines established by the International Streptomyces Project (Shirling, and Gottlieb, 1969). Microscopic characterization was done by cover slip culture method (Kawato and Shinobu, 1959). The mycelium structure, colour was observed under light microscope. The observed structure was compared with Bergey's manual of Determinative Bacteriology (Bergey, 2000) and the organism was identified. The utilization of different carbon and nitrogen sources were also analyzed (Pridham and Gottlieb, 1948).

\section{Screening for Enzyme Activity}

The isolates were screened for Lasparaginase enzyme activity by plate assay method with SCA spiked with $0.05 \%$ phenol red dye (Imada et al., 1973; Gulati et al., 1997). The plates were inoculated with $72 \mathrm{~h}$ old culture of the isolates as a test organism. The isolated cultures showed zone of pink coloration indicating a positive reaction.

\section{Partial Purification of L-asparaginase}

For crude enzyme preparation, 24 hours old actively growing isolate (KTI 7) was transferred to SCA broth containing asparagines $(0.1 \%)$ and grown at room temperature in a shaker at $100 \mathrm{rpm}$. After 72 hours of incubation, the broth was centrifuged to get cell free crude enzyme extract. Crude enzyme was used for the enzyme assay. The assay mixture containing
$0.25 \mathrm{ml}$ of crude enzyme extraction; $1.25 \mathrm{ml}$ of $0.2 \mathrm{M}$ borate buffer ( $\mathrm{pH} 8$ ) was added. Then $0.5 \mathrm{ml}$ of $0.04 \mathrm{M}$ L-asparagine in borate buffer was added and the mixture was incubated at $35^{\circ} \mathrm{C}$ for $30 \mathrm{~min}$. The reaction was stopped by the addition of $0.5 \mathrm{ml}$ of 15 $\%$ TCA and the assay mixture was subjected to centrifugation at $4,000 \mathrm{rpm}$ for $20 \mathrm{~min}$. After the centrifugation, the supernatant (1 $\mathrm{ml}$ ) was mixed with $4 \mathrm{ml}$ of sterilized distilled water free from ammonia. To this $0.5 \mathrm{ml}$ Nessler's reagent was added and the colour intensity read in a spectrophotometer at $450 \mathrm{~nm}$. Ammonia content was estimated using standard ammonium chloride solution and is expressed in International units (IU) per mg of protein (Benny and Ayyakkannu, 1992). Further purification of Lasparaginase was done by salting out method using ammonium sulphate precipitation and filtration.

\section{Salting out with Ammonium Suphate}

The crude enzyme prepared was brought to $45 \%$ saturation with ammonium sulphate at pH 8.4 and kept overnight in cold room. After that the supernatant was subjected to centrifugation at $4200 \mathrm{~g}$ for $10 \mathrm{~min}$ at $40^{\circ} \mathrm{C}$. After centrifugation the supernatant was brought to $85 \%$ saturation subjected to centrifugation at $4200 \mathrm{~g}$ for $10 \mathrm{~min}$ at $40^{\circ} \mathrm{C}$. Then the precipitate was collected separately and stored at $40^{\circ} \mathrm{C}$ for further purification.

\section{Dialysis}

The pre treated dialysis bag was used for dialysis of the precipitates collected previously. The precipitate collected after each of the $45 \%, 85 \%$ saturation steps were dissolved in $1 \mathrm{Mm}$ Tris $\mathrm{HCl}$ buffer and dialyzed overnight at $4^{\circ} \mathrm{C}$. After dialysis, the samples were used for protein estimation and enzyme assay (Benny and Ayyakannu, 1992). 


\section{Gel Filtration in Sephadex Column}

The dialysed sample were dissolved in 0.05 $\mathrm{M}$ Tris $\mathrm{HCl}(\mathrm{pH} \mathrm{8.4)}$ buffer and loaded on to pre equilibrated column with $0.05 \mathrm{~m}$ Tris $\mathrm{HCl}$ Sephdex G 50. It was eluted with 0.05 $\mathrm{M}$ tris HCL buffer containing $0.1 \mathrm{M}$ KCL. Fractions were collected at the flow rate of $5 \mathrm{~mL} / 30 \mathrm{~min}$ and L-asparaginase was assayed by procedure described earlier. Fractions showing high activity were pooled and freeze dried (Gaffar and Shethna, 1975).

\section{Results and Discussion}

\section{Characterization of the Sediment Samples}

Sediment samples had alkaline $\mathrm{pH}$ of 8.36 and 8.45 with an EC value of 7.54 and 5.89 $\mathrm{dSm}^{-1}$. Organic carbon content of the sediments were 1.32 and $1.42 \%$ (Table.1).

The collected sample had very low bacterial and fungal population. The samples recorded very low Actinomycetes population (4 to 100 / gram of sediment). Based on this observation enrichment was carried out before enumerating the Actinomycetes population

\section{Enrichment of Samples}

As far as colony growth pattern was concerned, the number of colonies formed was increased along with the number of days of incubation. Different types of morphology were observed. In Sea water Complex agar media large sized, white cottony growth was observed (Table 2 ).

\section{Isolates used for the Study}

From the enrichment culture totally eight different isolates were obtained. Three isolates from the sediment sample KTS 12 and 5 samples from KTS 13 were isolated and maintained for further use. Among the eight isolates, isolates which had enzyme activity in rapid plate assay were used for further study (fig.1). Three isolates showed asparaginase activity (KTI1, KTI 6 and KTI7).

\section{Identification of Actinomycetes}

The morphological, cultural and biochemical characteristics of the isolates were presented in table 1 .

\section{Morphological Characterization}

Most of the marine actinomycete isolates produced grey and white colonies without pigmentation and showed fast growth. The isolates showed white and dull white pigmentation with gram positive and acid fast reaction without motility(table 3).

\section{Biochemical Characterization}

All the isolates required $\mathrm{NaCl}$ for growth and can able to tolerate upto $5 \%$ concentration. These isolates grow well at ambient temperature with $\mathrm{pH}$ a range of 7-8. The isolates are catalase and oxidase negative and reduces nitrate. All the isolates showed MR positive reaction with VP negative results. The isolates showed gelatinase and amylase activity which was identified by gelatin liquefaction and starch degradation (table 4).

\section{Utilization of Carbon Sources}

All the isolates showed good growth when glucose was used as carbon source, but also grow well in mannitol and fructose containing media. Sucrose was not utilized by many of the isolates. The isolates KTI1,KTI6 and KTI7 prefers glucose as carbon source compared to other carbon sources, but grows well in Mannitol and fructose as carbon source. Innosital and Rhamnose were not utilized by the isolates. 
Even though hydrolysed casein and starch, these isolates were not able to hydrolyse cellulose. Sucrose was not a preferred carbon for all isolates (table 5).

\section{Utilization of Nitrogen Sources}

Differences were observed between isolates in case of nitrogen utilization. All the isolates utilized Lasparagine, but also utilized Leucine, Tyrosine. None of the isolates utilized L-phenylalanine and Lglutamine (table 6).

\section{Screening for L-asparaginase Activity}

The enzyme L asparagine was partially purified using ammonium sulphate and sephadex gel filtration. After $45 \%$ and 855 saturation with ammonium sulfate, the pellet was used for the estimation of protein and for L-asparaginase enzyme assay

The specific activity of the enzyme was increased, where as the totaal protein and total activity were decreased proportionaly (table 7). The different fractions which showed maximum activity was separated and lyophilised for further use (fig 2).

Out of 21 recommended media, SCA medium was selected to determine the efficacy for isolation, growth and activity of Actinomycetes from the marine sediment samples. From the enrichment cultures a total of 8 different Actinomycetes strains were recovered from sediment samples collected from Thiruvallam, Kerala using starch casein agar. This medium seems to be specific and sensitive for Actinomycetes, since it contains starch that most Actinomycetes use as a carbohydrate source and casein as nitrogen source. The salts of seawater provide complex ionic sources that make the medium suitable for marine microbial flora and also buffer the medium (Wellington and Cross, 1983). Among the eight isolates, 3 isolates which had significant enzyme activity in plate assay were used for further study.

Table.1 Physico - Chemical Analysis of the Sediment Samples

\begin{tabular}{|l|l|l|l|l|l|l|l|l|c|}
\hline $\begin{array}{l}\text { Sample } \\
\text { No }\end{array}$ & $\begin{array}{l}\text { Name of } \\
\text { the place }\end{array}$ & $\begin{array}{l}\text { Depth } \\
\text { and } \\
\text { method }\end{array}$ & $\begin{array}{l}\text { Sediment } \\
\text { type }\end{array}$ & $\mathbf{p H}$ & $\begin{array}{l}\mathbf{E C} \\
\mathbf{( d S m} \\
\mathbf{1})\end{array}$ & $\begin{array}{l}\text { OC } \\
(\boldsymbol{\%})\end{array}$ & $\mathbf{N}(\boldsymbol{\%})$ & $\mathbf{P}(\boldsymbol{\%})$ & $\begin{array}{c}\text { K } \\
(\boldsymbol{\%})\end{array}$ \\
\hline KTS12 & $\begin{array}{l}\text { Thiruvallum } \\
- \text { Kerala }\end{array}$ & $\begin{array}{l}\text { 6 feet, } \\
\text { manual }\end{array}$ & $\begin{array}{l}\text { Sediment } \\
\text { with dark } \\
\text { sandy soil }\end{array}$ & 8.45 & 7.54 & 1.41 & 0.39 & 0.03 & 0.006 \\
\hline KTS13 & $\begin{array}{l}\text { Thiruvallum } \\
- \text { Kerala }\end{array}$ & $\begin{array}{l}\text { 6 feet, } \\
\text { manual }\end{array}$ & $\begin{array}{l}\text { Sediment } \\
\text { with dark } \\
\text { sandy soil }\end{array}$ & 9.06 & 5.89 & 0.38 & 0.42 & 0.02 & 0.001 \\
\hline
\end{tabular}

Table.2 Isolation of Actinomycetes from Different Sediment Samples

\begin{tabular}{|l|l|c|c|c|}
\hline \multirow{2}{*}{$\begin{array}{l}\text { Sample } \\
\text { No }\end{array}$} & \multirow{2}{*}{ Name of the place } & \multicolumn{3}{|c|}{ Sea Water Complex Agar } \\
\cline { 3 - 5 } & & 5 DAI & 10 DAI & 15 DAI \\
\hline KTS12 & Thiruvallum -Kerala & 2 & 18 & 20 \\
\hline KTS13 & Thiruvallum -Kerala & 7 & 34 & 34 \\
\hline
\end{tabular}

DAI - Days after incubation 
Int.J.Curr.Res.Aca.Rev.2016; 4(4): 88-97

Table.3 Morphological Characteristics of the Isolates from Marine Sediments

\begin{tabular}{|l|l|l|l|}
\hline \multirow{2}{*}{ Characteristics } & \multicolumn{3}{|c|}{ Actinomycetes } \\
\cline { 2 - 4 } & KTI1 & KTI 6 & KTI7 \\
\hline Mycelium limit & Positive & Positive & Positive \\
\hline Colony color & Dull white & White & Dull white \\
\hline Motility & Non motile & Non motile & Non motile \\
\hline Gram staining & Gram Positive & Gram Positive & Gram Positive \\
\hline Acid fast & Negative & Negative & Negative \\
\hline
\end{tabular}

Table.4 Biochemical Characterization of the Isolates from Thiruvallum, Kerala

\begin{tabular}{|l|c|c|c|}
\hline \multirow{2}{*}{ Characteristics } & \multicolumn{3}{|c|}{ Promising Isolates } \\
\cline { 2 - 4 } & KTI1 & KTI 6 & KTI7 \\
\hline NaCl requirement 5\% (w/v) & + & + & + \\
\hline Optimum temperature & $37-40^{\circ} \mathrm{C}$ & $37-40^{\circ} \mathrm{C}$ & $37-40^{\circ} \mathrm{C}$ \\
\hline Optimum pH range & $7-8$ & $7-8$ & $7-8$ \\
\hline Catalase activity & - & - & - \\
\hline Oxidase & - & - & - \\
\hline Nitrate reduction & + & + & + \\
\hline Methyl red & + & + & + \\
\hline Voges Proskeur & - & - & + \\
\hline Gelatin utilization & + & + & + \\
\hline Starch degradation & + & + & - \\
\hline Casein hydrolysis & + & + & + \\
\hline $\begin{array}{l}\text { Growth in the presence of } 0.1 \% \\
\text { phenol }\end{array}$ & - & - & \\
\hline
\end{tabular}

Table.5 Utilization of Carbon Sources

\begin{tabular}{|l|l|l|l|}
\hline \multirow{2}{*}{ Carbon sources } & \multicolumn{3}{|c|}{ Promising Isolates } \\
\cline { 2 - 4 } & \multicolumn{1}{|c|}{ KTI1 } & \multicolumn{1}{c|}{ KTI 6 } & \multicolumn{1}{c|}{ KTI 7 } \\
\hline Glucose & $\begin{array}{c}\text { Strongly } \\
\text { Utilized }\end{array}$ & Strongly Utilized & Strongly Utilized \\
\hline Arbinose & Utilized & Utilized & Utilized \\
\hline Sucrose & Utilized & Utilized & Not utilized- \\
\hline Mannitol & Utilized & Utilized & Utilized \\
\hline Fructose & Utilized & Utilized & Utilized \\
\hline Inositol & Utilized & Not Utilized & Utilized \\
\hline Xylose & Utilized & Utilized & Utilized \\
\hline Fructose & Utilized & Utilized & Utilized \\
\hline Rhamnose & Not Utilized & Utilized & Not Utilized \\
\hline Cellulose & Not Utilized & Not Utilized & Not Utilized \\
\hline
\end{tabular}


Int.J.Curr.Res.Aca.Rev.2016; 4(4): 88-97

Table.6 Utilization of Nitrogen Sources

\begin{tabular}{|l|l|l|l|}
\hline \multirow{2}{*}{ Sources } & \multicolumn{3}{|c|}{ Actinomycetes } \\
\cline { 2 - 4 } & \multicolumn{1}{|c|}{ KTI1 } & \multicolumn{1}{c|}{ KTI 6 } & \multicolumn{1}{c|}{ KTI 7 } \\
\hline L-asparagine & + & ++ & ++ \\
\hline Leucine & + & + & ++ \\
\hline Tyrosine & + & + & ++ \\
\hline L-phenylalanine & - & - & - \\
\hline L-glutamine & - & - & - \\
+-- Indicates positive, & -- Indicates negative, \\
++ -- Indicates strongly positive, & $\mathrm{v}-$ Indicates variable
\end{tabular}

Table.7 Purification of L-asparaginase Enzyme from Marine Actinomycetes

\begin{tabular}{|l|c|c|c|}
\hline \multicolumn{1}{|c|}{ Purification Steps } & $\begin{array}{c}\text { Total protein } \\
(\mathrm{mg})\end{array}$ & $\begin{array}{c}\text { Total Activity } \\
(\mathrm{IU})\end{array}$ & Specific Activity ( IU) \\
\hline Crude extract & 389.5 & 244.5 & 0.52 \\
\hline $\begin{array}{l}\text { Ammonium Sulphate } \\
\text { precipitation 45-85\% }\end{array}$ & 214.2 & 192.8 & 0.68 \\
\hline $\begin{array}{l}\text { Sephadex G 50 } \\
\text { filtration }\end{array}$ & 1.06 & 22.26 & 1.08 \\
\hline
\end{tabular}
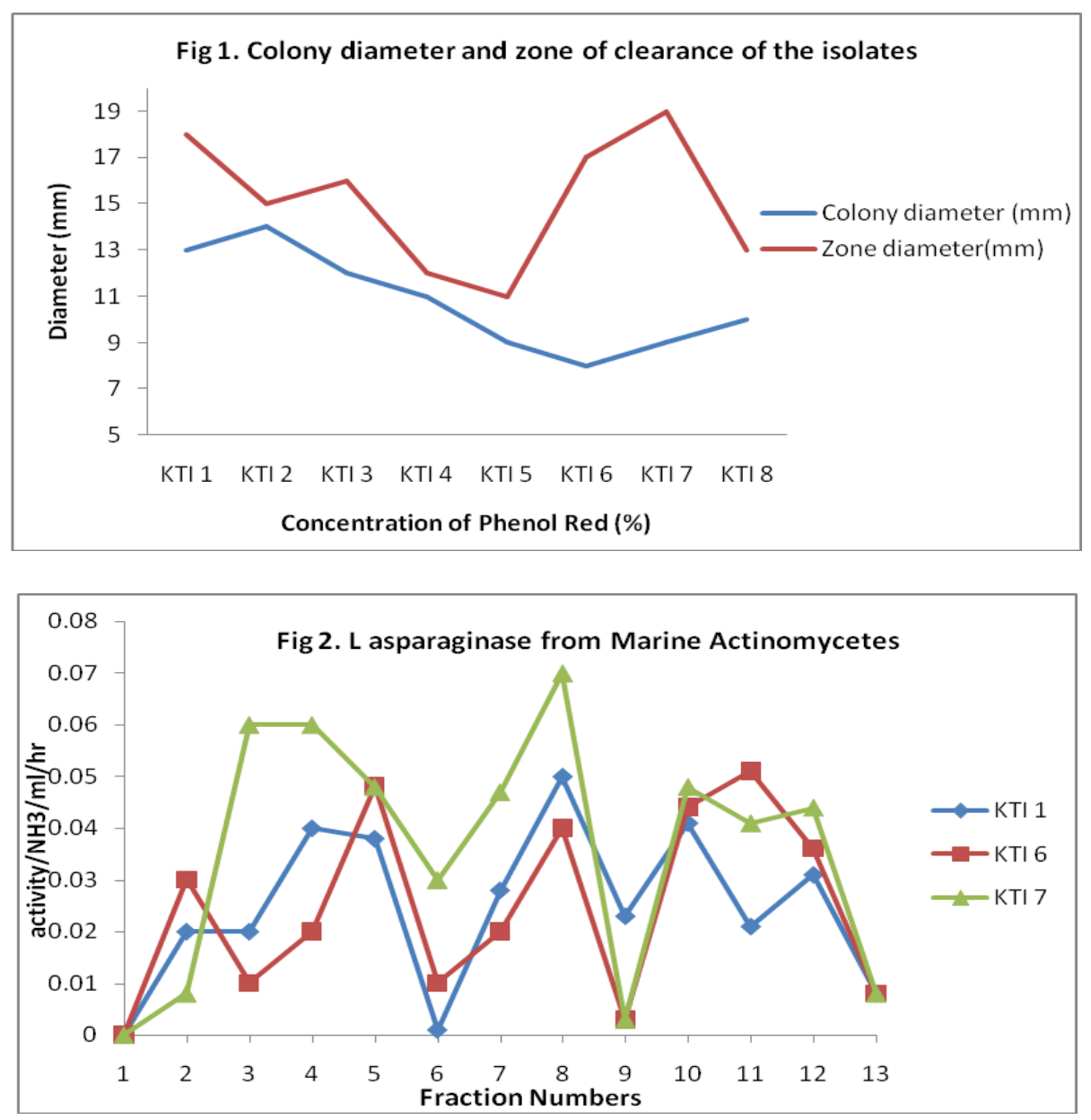
The therapeutic use of L-asparaginase from previously used sources was limited due to immunological responses. L-Asparaginase from bacterial origin has several issues like hypersensitivity due to long-term use leading to allergic reactions and anaphylaxis (Ahlke et al., 1997), asparaginase resistance (Worton, et al., 1991), leukemoginicity (Puri et al., 1995), and glutaminase activity (Ramya et al., 2012). So, due to all these factors, there is a need for newer asparaginases with new immunological properties.

Microorganisms from extreme environments like marine water and hypersaline lakes are expected to have halophilic proteins and enzymes with modified structure and different immunological properties, hence L-asparaginase from these halophilic organisms may be used in the treatment for hypersensitive patients (Ebrahiminezhad et al 2011). In the current study, an Lasparaginase producing organism was isolated from marine sediment of Thiruvallum, Kerala.

The outcome of this project highlighted the potential of marine environment, where therapeutic enzymes from marine actinomycetes might be harnessed. Studies have shown that marine actinobacteria were found to be a good source for therapeutic Lasparaginase. However these studies have been completed only upon the isolation of marine actinobacteria from marine environment for screening of L-asparaginase potentials. Thus further substantial research is needed to explore the potential of marine actinomycetes. Despite some of the potential hindrances to the extraction of enzymes from actinomycetes, the current awareness regarding the compounds from biological origin indicates that marine actinomycete application to therapeutic industry deserves attention.

\section{Acknowledgement}

The authors are thankful to the University Grants Commission, Government of India for their financial support.

\section{References}

Adams, M.W.W., Perler, F.B., Kelly, R.M. 1995. Extremozymes: Expanding the limits of biocatalysts. Nat. Biotechnol., 13: 662-668.

Ahlke, E., Nowak-Gottl, U., SchulzeWesthoff, P., Werber, G., Borste, H., Wurthwein, G. 1997. Dose reduction of asparaginase under pharmacokinetic and pharmacodynamic control during induction therapy in children with acute lymphoblastic leukaemia. Br. J. Haematol., 96: 675-681.

Alapati, K., Muvva, V. 2012. A study on Lasparaginase of Nocardia lecis $\mathrm{MK}$ VL 113. The Scientific World J., http://www.hindawi.com/journals/tswj /2012/160/434/

APHA. 1989. Standard methods for estimation of water and wastewater, 16th Edn.American Public Health Association. Washington DC.

Baharum, S.N., Beng, E.K., Mouhtar, M.A.A.2010. Marine Microorganisms: Potentail Application and Challenges. J. Biol. Sci., 10: 555-564.

Benny, A., Ayyakkannu. 1992. Lasparaginase activity of benthic marine bacteria and of the muricid Gasteropod chicoreus ramosus,East coast of india., Phuket Mar. Biol Spec. Publ. No. 11: 137- 140.

Bergey, 2000. Manual of determinative bacteriology. Actinomycetales, 9th ed.

Broome, J.D. 1971. Relationship between Lasparaginase and L-glutaminase in tumour inhibition. In Colloque sur la L-asparaginase. Colloqye du CNRS 
no.I97. Paris:Edition du Centre

National de la Recherche Scientific.

Cappuccino, J.G., Sherman, N. 2002.

Microbiology: A laboratory manual, 6

th addition, Pearson education

(Singapore) Pvt. Ltd, Indian branch,

482 FIE Patparganj, New Delhi, 143185.

Dhevagi, P., Poorani. E. 2006. Isolation and characterization of L-asparaginase from marine actinomycetes. Indian $J$.

Biotechnol., 5: 521-526.

Ebrahiminezhad, A., Rasoul-Amini, S., Ghasemi, Y. 2011. L-Asparaginase production by Moderate Halophilic bacteria isolated from Maharloo Salt Lake. Indian J. Microbiol., 51: 307311.

Ellaiah, P., Reddy, A.P.C. 1987. Isolation of actinomycetes from marine sediments of Vishakapatnam East coast of India. Indian. J. Mar. Sci., 16: 134-135.

Gaffar, S.A., Shethna, Y.I. 1975. partial Purification and antitumour activity of L-asparaginase from AZotobacter vinelandi, Curr. Sci., 44: 727-729.

Gulati, R., Saxena, R.K., Gupta, R. 1997. A rapid screening for $\mathrm{L}$-asparaginase producing microorganisms. Lett. Appl. Microbiol., 24: 23-26.

Imada, A., Igarasi, S., Nakahama, K., Isono, M. 1973. Asparaginase and glutaminase activities of microorganisms. J. Gen. Microbiol., 76: 85-89.

Kawato, M., Shinobu, R. 1959. Cover slip culture of Streptomyces herbaricolour nov. sp. Supplement a simple technique for the microscopic observation. Mem. Osaka. Univ. Lib. Art. Educ., 8: 114-119.

Kotzia, G.A., Labrou, N.E. 2007. LAsparaginase from Erwinia Chrysanthemi 3937: cloning, expression and characterization. $J$. Biotechnol., 127: 657-669.
Lee, S.M., Wrabla, M.K., Ross, J.T. 1989. L-asparaginase from Erwinia Carotovora.- An improved recovery and purufucation process using affinity chromatography. Appl. Biochem. Biotechnol., 22: 1-11.

Narta, U., Roy, S., Kanwar, S.S., Azmi, W. 2011. Improved production of Lasparaginase by Bacillus brevis cultivated in the presence of oxygenvectors. Biores. Technol., 102: 20832085.

Newman, D.J., Hill, R.T. 2006. New drugs from marine microbes: the tide is turning. J. Ind. Microbiol. Biotechnol., 33: 539-544.

Prakasham, R.S., Hymavathi, M., Rao, S., Arepalli, S.K., Rao, V.J., Kennady, P.K. 2010, Evaluation of antineoplastic activity of extracellular asparaginase produced by isolated Bacillus circulans. Appl. Biochem. Biotechnol., 160: 72-80.

Pridham, T.G., Gottlieb, D. 1948. The utilization of carbon compounds by some Actinomycetales as an aid for species determination. J. Bacteriol., 56: 107-114.

Pui, C., Relling, M., Behm, F., Hancock, M., Boyett, J., Raimondi, S. 1995. Lasparaginase may potentiate the leukemogenic effect of the epipodophyllotoxins. Leuk., 9: 16801684.

Ramya, L.N., Doble, M., Rekha, V.P., Pulicherla, K.K. 2012. L-Asparaginase as potent anti-leukemic agent and its significance of having reduced glutaminase side activity for better treatment of acute lymphoblastic leukemia. Appl. Biochem. Biotechnol., 167: 2144-2159.

Sabu, A. 2003. Sources,properties and applications of microbial therapeutic enzymes. Indian Jr. Biotechnol., 2 p: 334-341. 
Savitri, A.N., Azmi, W. 2003. Microbial Lasparaginase : A potent antitumour enzymes. Indian Jr. Biotechnol., 2: 184-194.

Selvakumar, N., Chandramohan, D., Natarajan, R. 1977. L-asparaginase activity in marine sediments. Curr. Sci., 46(9): 287-291.

Shirling, E., Gottlieb, D. 1969. Cooperative description of type cultures of Streptomyces. IV Species description from the second, third and fourth studied. Int. J. Systematic Evol. Microbiol., 19: 391-512.

Sindhwd, P., Desai, K. 2015. media optimization, Isolation and purification of L-asparaginase from marine isolate. Asian Pac. J. Health Sci., 293: 72-82.

Thenmozhi, C., Sankar, R., Karuppiah, V., Sampathkumar, P. 2011. Lasparaginase production by mangrove derived Bacillus cereus MAB5:
Optimization by response surface methodology. Asian Pac. J. Trop. Med., 4: 486-491.

Waksman, S.A. 1961. The Actinomycetes: Classification, identification and descriptions of genera and species. The Williams and Wilkins Company, Baltimore 2: 61-292.

Wellington, E.M.H., Cross, T. 1983. Taxonomy of antibiotic producing Actinomycetes and new approaches to their selective isolation. In: "Progress in industrial microbiology?" Bushell, M.E. (eds.). Elsevier, Amsterdam, pp: 36.

Worton, K.S., Kerbel, R.S., Andrulis, I.L. 1991. Hypomethylation and reactivation of the asparagine synthetase gene induced by Lasparaginase and ethyl methanesulfonate. Cancer Res., 51: 985-989.

\section{How to cite this article:}

Dhevagi, P., and Poorani, E. 2016. Isolation of L-asparaginase Producing Actinomycetes from Marine Sediments. Int.J.Curr.Res.Aca.Rev.4(4): 88-97. doi: http://dx.doi.org/10.20546/ijcrar.2016.404.011 